\title{
ST
}

Science \& Technology

PAPER - OPEN ACCESS

\section{Analisa XRD Terhadap Perubahan Struktur Dan Kristalinitas Karbonisasi Batubara Sawahlunto - Sijunjung Sumatera Barat}

\author{
Author : Vivi Purwandari dkk., \\ DOI $\quad: 10.32734 /$ st.v2i1.321 \\ Electronic ISSN $\quad: 2654-7082$ \\ Print ISSN : :2654-7074
}

Volume 2 Issue 1 - 2018 TALENTA Conference Series: Science \& Technology (ST)

This work is licensed under a Creative Commons Attribution-NoDerivatives 4.0 International License.

Published under licence by TALENTA Publisher, Universitas Sumatera Utara

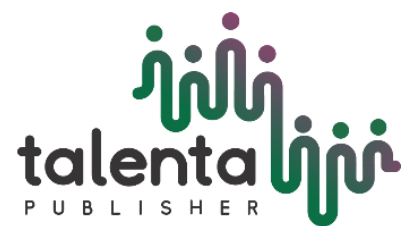




\title{
jibiti

\section{Analisa XRD Terhadap Perubahan Struktur Dan Kristalinitas Karbonisasi Batubara Sawahlunto - Sijunjung Sumatera Barat}

\author{
Vivi Purwandari ${ }^{\mathrm{a}^{*}}$, Saharman Gea ${ }^{\mathrm{b}}$, Basuki Wirjosentono ${ }^{\mathrm{b}}$ \\ ${ }^{a}$ Mahasiswa Program Doktor Universitas Sumatera Utara \\ ${ }^{b}$ Universitas Sumatera Utara \\ vivi_purwandari@yahoo.com
}

\begin{abstract}
Abstrak
Indonesia memiliki kekayaan alam yang sangat luar biasa. Salah satu kekayaan alam Indonesia adalah bahan tambang batubara, Sawahlunto merupakan satu dari sekian banyak daerah penghasil batubara. Batubara di Sawahlunto memiliki perbedaan dari daerah lain karena memiliki kalori yang cukup tinggi dan lebih rapuh. Batubara adalah sumber energi paling melimpah dan mudah terbakar yang digunakan di seluruh dunia. Namun, karakteristik strukturalnya menciptakan persepsi bahwa batu bara hanya berguna untuk menghasilkan energi melalui pembakaran. Penelitian ini bertujuan untuk mengetahui perubahan struktur dan kristalinitas yang terjadi akibat kenaikan suhu selama proses karbonisasi, sehingga batubara dapat dimanfaatkan sebagai bahan baku pengganti grafit dalam pembuatan grafena. Karbonisasi batubara dilakukan pada suhu $400^{\circ} \mathrm{C}, 600^{\circ} \mathrm{C}, 900^{\circ} \mathrm{C}$ dan $1200^{\circ} \mathrm{C}$. Perubahan struktur dan kristalinitas dikarakterisasi dengan XRD. Hasil menunjukkan bahwa ada perubahan struktur dan kristalinitas seiring dengan meningkatnya suhu karbonisasi.
\end{abstract}

Kata Kunci: batubara; karbonisasi; kristalinitas;

\section{Pendahuluan}

Analisa difraksi sinar-X (XRD) merupakan metode dasar untuk mengevaluasi struktur susunan karbon. Derajat grafitisasi, jarak interlayer (d002), dan ukuran kristal (La, Lc) telah ditetapkan sebagai struktur susunan material karbon kritalinitas tinggi. Struktur batubara juga dikarakterisasi oleh XRD, dan adanya kristalit dalam struktur batubara dibuktikan oleh munculnya puncak 002, 100 dan 110 [1]. XRD sangat bermanfaat untuk mendapatkan informasi struktural dan karakter batubara Perubahan struktur kristal batubara selama konversi dapat diamati dengan spektra char/ash analisis XRD. Analisa XRD dapat mengungkapkan perubahan signifikan dalam ukuran kristal untuk sampel hasil karbonisasi pada rentang temperatur yang luas $\left(900-1500^{\circ} \mathrm{C}\right)[2]$

Batubara merupakan karbon alami dengan sifat fisikokimia bervariasi sesuai dengan lokasi asal batubara tersebut. Berbagai macam bahan organik dan anorganik terlibat dalam formasi batubara membuat batubara menjadi sangat heterogen, baik struktur fisika ataupun kimia. Katakterisasi struktural batubara salah satu dari kegiatan yang paling penting dalam mempelajari penggunaan batubara [3]. Batu bara dapat menjadi sumber yang baik untuk menggantikan grafit sebagai bahan baku karena murah dan berlimpah. Struktur batubara cukup kompleks, komposisi yang disederhanakan mengandung domain karbon kristal berukuran nanometer dengan cacat yang terkait dengan karbon amorf alifatik [4]. Batubara masih banyak digunakan sebagai sumber energi, berbeda dengan alotrop karbon kristal seperti fullerene, graphene, grafit dan berlian yang telah menemukan aplikasi dalam elektronik, fisika, kimia dan biologi [5].

Batu bara Sawahlunto - Sijunjung terdapat dalam wilayah Kecamatan Kamang Utara, Walinagasari Kamang, Jorong Sungai Tambangan Kabupaten Sawahlunto-Sijunjung, Berdasarkan analisa yang dilakukan oleh PT. Sucofindo merupakan analisa Proksimat terhadap sejumlah contoh batubara Sawahlunto - Sijunjung mempunyai kisaran kualitas 
sebagai berikut (Tabel 1), dari kualitas tersebut di atas, maka batubara Sawahlunto - Sijunjung diigolongkan ke dalam klasifikasi batubara jenis High Volatile A Bituminous Coal. [5]

Tabel 1. Kualitas Batubara Sungai Tambangan (A.Said, 2002)

\begin{tabular}{lll}
\hline No. & Parameter & Daerah Sungai Tambangan \\
\hline 1 & Total Moisture & $10-13 \%$ \\
2 & Proximate Analysis & \\
& Inherent Moisture & $6.62-11.54 \%$ \\
& Volatile Matter & $32.32-40.08 \%$ \\
& Fixed Carbon & $40.79-49.67 \%$ \\
& Ash Content & $5.01-21.13 \%$ \\
3 & Total Sulfur & $1.64-2.34 \%$ \\
4 & Caloric Val & $5400-6900 \mathrm{Kcal} / \mathrm{kg}$ \\
5 & HGI & -48 \\
\hline
\end{tabular}

Metode karbonisasi yang didukung dengan hidrotermal memiliki keunggulan dalam morfologi karbon sesuai dengan suhu reaktor [6]. Pada suhu reaktor yang tinggi $\left(300-800^{\circ} \mathrm{C}\right)$ akan diperoleh karbon yang berupa nanotube, grafit dan karbon aktif [7].

Proses karbonisasi suhu $400-1200^{\circ} \mathrm{C}$ terhadap batubara Sawahlunto-Sijunjung dalam penelitian ini dilakukan untuk mendapatkan struktur karbon grafit, yaitu mendapatkan kristalinitas karbon terbaik, sehingga batubara ini dapat dimanfaat sebagai bahan baku dalam pembuatan grafena oksida dan grafena.

\section{Metode}

\subsection{Persiapan sampel dan proses karbonisasi}

Batubara dihaluskan dan diayak dengan ayakan berukuran 325 mesh. Kemudian ditimbang 10 gram dan dimasukkan ke dalam gelas crusibel lalu ditutup (dilakukan untuk 4 buah gelas crusibel). Sampel kemudian dimasukkan ke dalam Tanur dan dilakukan pemanasan $400^{\circ} \mathrm{C}, 600^{\circ} \mathrm{C}, 900^{\circ} \mathrm{C}$ dan $1200^{\circ} \mathrm{C}$.

\subsection{Analisa XRD}

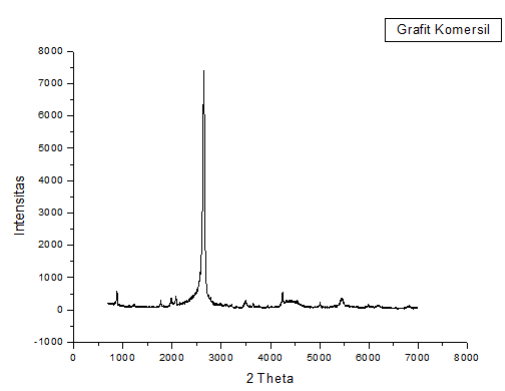

(a) Grafit Komersial

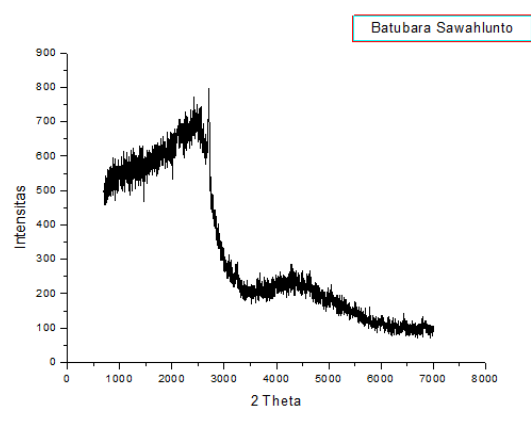

(b) Batubara Sawahlunto 


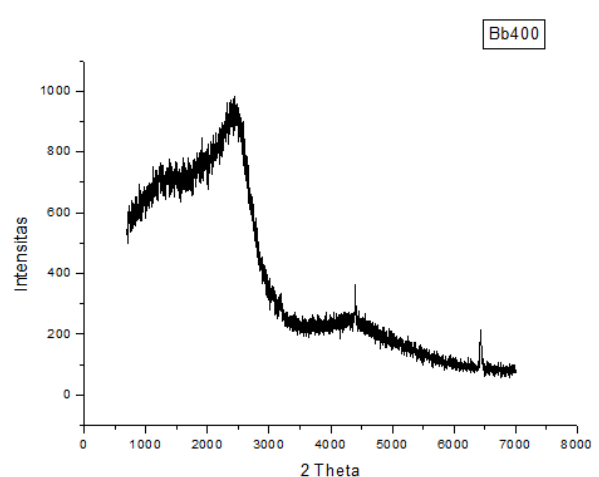

(c) $\mathrm{Bb} 400^{\circ} \mathrm{C}$

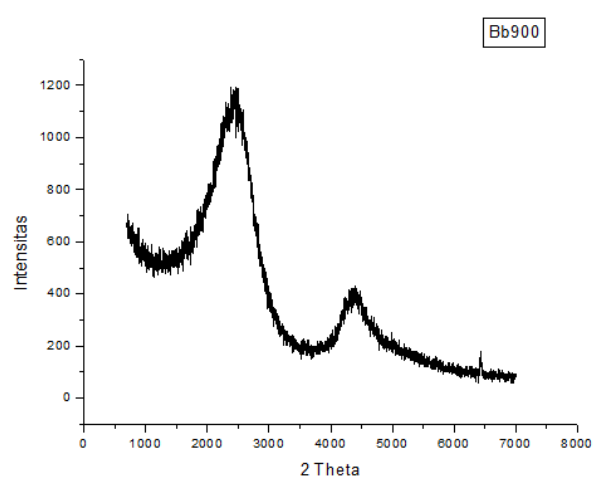

(e) $\mathrm{Bb} 900^{\circ} \mathrm{C}$

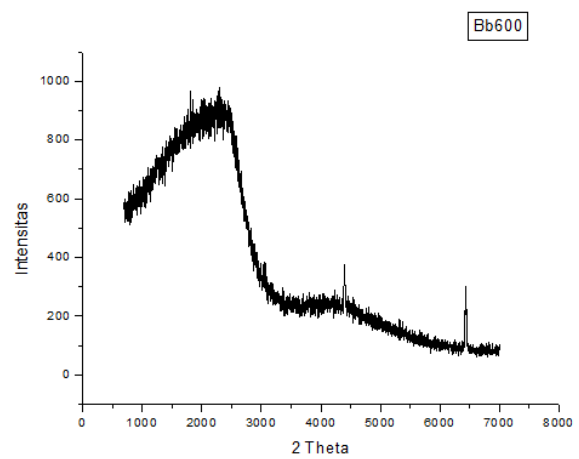

(d) $\mathrm{Bb} 600^{\circ} \mathrm{C}$

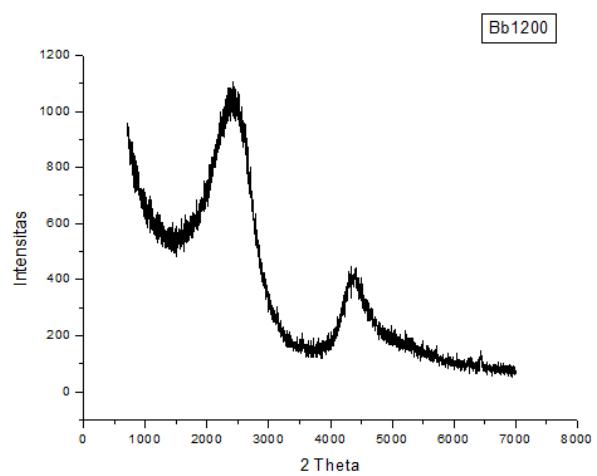

(f) $\mathrm{Bb} 1200^{\circ} \mathrm{C}$

Gambar 1. XRD

Gambar 1 memperlihatkan puncak $2 \Theta=20-30^{\circ}$ sesuai dengan refleksi yang sebabkan susunan lapisan struktur aromatis. Pelebaran puncak 002 berhubungan dengan dimensi kecil kristalin yang tegak lurus dengan lapisan aromatik [9]. Gambar 1a menunjukkan pumcak 002 dari grafit, $1 \mathrm{~b}$ merupakan spektrum XRD dari Batubara Sawahlunto, peak $2 \Theta$ di 25 dan $42^{\circ}$ hal ini menunjukkan mayoritas karbon merupakan grafit [10]. Puncak batu bara hasil karbonisasi juga menunjukkan peak $2 \Theta$ yang hampir sama. Namun, kristalinitas lebih tinggi pada batubara hasil karbonisasi suhu $900^{\circ} \mathrm{C}$ dan $1200^{\circ} \mathrm{C}$ ditunjukkan dengan kedua peak yang lebih tajam. Dari analisa XRD terhadap batubara hasil karbonisasi didapat bahwa karbonisasi yang dilakukan pada suhu $900^{\circ} \mathrm{C}$ memiliki susunan lapisan struktur aromatis dari grafit dengan kritalinitas yang lebih baik jika dibandingkan hasil karbonisasi suhu $400^{\circ} \mathrm{C}, 600^{\circ} \mathrm{C}$ dan $1200^{\circ} \mathrm{C}$.

\section{Kesimpulan}

Dari hasil analisa XRD batubara Sawahlunto-Sijunjung dan batubara hasil karbonisasi diperoleh bahwa karbonisasi yang dilakukan pada suhu $900^{\circ} \mathrm{C}$ memiliki susunan lapisan struktur karbon aromatis dengan kristalitas terbaik dibandingkan perlakuan karbonisasi pada suhu $400^{\circ} \mathrm{C}, 600^{\circ} \mathrm{C}$ dan $1200^{\circ} \mathrm{C}$. Sehingga untuk mensintesa grafena oksida atau grafena yang berasal dari batubara Sawahlunto-Sijunjung didahului dengan proses karbonisasi pada suhu $900^{\circ} \mathrm{C}$. Batubara Sawahlunto-Sijunjung dapat menggantikan grafit sebagai bahan baku pembuatan grafena.

Untuk hasil karbonisasi yang lebih baik, lebih baik dilakukan demineralisasi dengan $\mathrm{HF}$ dan $\mathrm{HCl}$ sebelum proses karbonisasi dilakukan.

\section{Referensi}

[1] Takagi H., Maruyama K., Yoshizawa N., Yamada Y., Sato Y., (2004), "XRD analysis carbon stacking structure in coal during heat treatment", Fuel, 83, 2427-2483

[2] Gupta R., (2007), “Advanced Coal Characterization : A Review”, Energy and Fuel. 
[3] Saikia K B., Boruah K R., Gogol K P., (2009), “A S-ray analysis on graphene layers of Assam coal”, J.Chem.Sci, 121, 103-106

[4] Yel R., Xiang C., Lin J., (2013), “Coal as abudant source of graphene”, Nature Communication, 4.2943, 1-6

[5] Kumar S E., Sivansankar V., Sureshbabu R., Raghu S., Kalaivani R A., (2017), "Facile synthesis of few layer graphene from bitumunous coal and its application towards electrochemical sensing of caffein", Advanced Materials Letters, 8(3), 239-245

[6] Antal M J., Gronli M., (2003), “The Art, Science, and Technology of Charcoal Production”, Ind.Eng.Chem.Res, 42, 1619-1640

[7] Said A., Lahar H., Soetrisno, Bagdja M., (2002), Pendataan Bahan Galian Tertinggal Dalam Tambang Di Kabupaten Sawahlunto-Sijunjung Provinsi Sumatera Barat, Kolokium Direktorat Inventarisasi Sumber Daya Mineral (DIM).

[8] Rahman T., Fadhlulloh A M., Nandiyanto D B A., Mudzakir A., (2015)," Review : Sintesis Karbon Nanopartikel”, Jurnal Integrasi Proses, $5(3), 120-131$

[9] Kim D Y., Nishiyama Y., Wada M., Kuga S., (2001), “Graphitization of highly crystalline cellulose”, Carbon, 39, 1051-1056

[10] Lu L., Sahajwalla V., Kong C., Harris D., (2001), "Quantitative X-Ray diffraction analysis and its aplication to various coals", Carbon, 39, $1821-1833$ 